\title{
The effect of herbs on the microbiological stability and nutritional quality of pariser
}

\author{
Miklós Posgay - Erika Lakatos - Viktória Kapcsándi \\ Department of Food Science, Faculty of Agricultural and Food Sciences, Széchenyi István University \\ posgay.miklos@sze.hu
}

SUMMARY

\begin{abstract}
The purpose of this study was to evaluate the functional properties of dried herbs (Thymus vulgaris L., Origanum vulgare L., Salvia officinalis L.) to improve the quality characteristics and microbiological stability of Hungarian meat product, pariser. The addition of herbs did not affect the microbial properties of the product. According to the Decree No. 4 of 1998 of the Ministry of Health, pariser can be considered safe. The nutritional quality of the different forms of pariser was also acceptable. However, the addition of oregano, sage and thyme changed the flavor characteristics of the parisers and the higher meat content would increase the final price of the product.
\end{abstract}

Keywords: pariser, herbs, antimicrobial effect

\section{INTRODUCTION}

In our rapidly evolving world the demands of the consumers for preservative-free products are evolving too. Partly thanks to the evolving healt awareness. Certain groups of products have high water activity and high, easily accessible nutrients for various microorganisms. These products have shorter shelf-life which however could be extended by preservatives from natural origin.

In our life meat and meat products have important roles. Without the daily consumption of meat and meat products we would suffer from illnesses, thanks to the lack of nutrients by animal products such as essential amino acids. Our diet should consist of animal and plant originated products too, to maintain our health.

Herbs contains different qualities and quantities of active ingredients which can have static or bactericidal effects on microorganisms. The effects depend on lots of factors, for example the concentration of the materials, duration of treatment, $\mathrm{pH}$, temperature, the resistance and strength of the microorganism, method of application, the storage time of herbs and temperature. The use of herbs can improve the self-life of meat products thanks to their components.

Of course herbs can use thanks to their pleasant taste too, not only their effects.

In the literature we can nearly only find articles about using of extracts, especially essential oils, which contains the active components in higher concentrations. In these oils the components are mainly terpenes, alcohols, aldehydes ketones, esters, phenol, lactones, sulphur and nitrogen compounds. In Hungary usage of essential oils are not regulated by law, but we should you them cautiously because their side effects (Agaoglu et al., 2007).

In thyme and oregano the antimicrobial components are terpenes, caracoles, p-cimenes, and thymol, while in sage $\alpha$-thujone, 1-8-cineole, camphor (Chen et al., 2008; Craft et al., 2017).

The antimicrobial components expose their effects on several places in a bacterial or fungal cell. They have effect on the cell membrane, which can lead to the prokaryotic or eukaryotic cell necrosis. The cell wall and membrane are important cellular components for example they separate the cell from the environment, they regulate the transport of the nutrients, ions, and without the regulation and separation the cell cannot exist. Essential oils also contain lipophilic components which can easily cross the cell wall or membrane, then accumulate on the cytoplasmic membrane thereby altering the membrane stability, the hydrophobic properties and fatty acid composition of the membrane. In bacteria the plasma membrane disruption results loss of RNA, proteins and ions for example potassium ion which is essential for maintaining the osmotic equilibrium, glucose metabolism, and activation of cellular enzymes, and these can lead to the cell death. Essential oils can destabilize the cell membrane architecture, which lead to the disruption of the proton pumps, and these effects cause uncontrolled hydrogen ion currents which will lower the $\mathrm{pH}$ inside the cell (Bakkali et al., 2008; Sikkema et al., 1995).

These active components has static or bactericidal effects against several human pathogenic microorganisms, for example Listeria monocytogenes, Salmonella Typhimurium, Escherichia coli 0157:H7, Shigella dysenteriae, Bacillus cereus and Staphylococcus aureus. There are plants which have stronger effect on for example bacterias, oregano (Origanum vulgare), cinnamon (Cinnamomum), rosemary (Rosmarinus officinalis), thyme (Thymus vulgaris) or sage (Salvia officinalis), nevertheless there are several which has less effect like ginger (Zingiber officinale), chilli (Capsicum annuum), and cumin (Carum carvi) (Burt, 2004; Burt et al., 2007; Holley and Patel, 2005; Mosqueda-Melgar et al., 2008).

For our study we chose a well-known Hungarian meat product, the pariser. We made four variation, one with only the pariser base mix spice, and three other with thyme (Thymus vulgaris), sage (Salvia officinalis) and oregano (Origanum vulgare).

\section{MATERIALS AND METHODS}

The pork meat and fat were obtained from a local butcher, SZA-SZE Hús Ltd (Mosonmagyaróvár, Hungary). The used pariser spice was from the Solvent 
Trading House Ltd (Budapest, Hungary). The dried oregano, thyme and sage (Kotányi Hungary Spices Processing and Sales Ltd, Törökbálint, Hungary) were purchased from the local shop.

\section{Ingredients}

The raw materials we used for our study we bought from the butcher shop SZA-SZE Hús Ltd from Mosonmagyaróvár. We ordered the pariser's spice from the Solvent Trading House Ltd. The tyhme (Kotányi Hungary Spices Processing and Sales Ltd, Törökbálint, Hungary), sage (Kotányi Hungary Spices Processing and Sales Ltd, Törökbálint, Hungary) and oregano (Kotányi Hungary Spices Processing and Sales Ltd, Törökbálint, Hungary) were obtained from commercial market, in dried form.

\section{Preparation of pork pariser}

Pariser samples were prepared on the preliminary studies conducted at our laboratory. Moreover, we followed the quality standards of the Directive 1-3/131 of the Codex Alimentarius Hungaricus. Pork meat, pork fat tissue and ice flakes were used for preparing pariser samples.

The raw materials were frozen overnight at $-20^{\circ} \mathrm{C}$. Freezing procedure is necessary to keep the temperature of meat paste as low as possible during the production. The frozen meat and fat were ground in a Nagema FGK-E10 (Nagema Ltd, Dresden, Germany) cutter. Water was added in the form of ice flakes to keep the paste cool. After the consistency of the meat paste was completely homogeneous we added the pariser spice to the paste. For $4 \mathrm{~kg}$ of meat paste we used $50 \mathrm{~g}$ of pariser spice and $5 \mathrm{~g}$ of dried herbs. During the production core temperature did not reach $0{ }^{\circ} \mathrm{C}$. Nevertheless, the used amount of pariser spice did not enhance the flavour of the meat paste efficiently, so we added $50 \mathrm{~g}$ of spice again.

The paste was stuffed by hand into artificial casings and the casings were tied with plastic bandages at both ends. The average weight of the rods was $230 \pm 20 \mathrm{~g}$. The sausages, after stuffing inside the casings, were vacuum packed in sous vid bags, and stored chilled overnight under refrigeration temperature $\left(4^{\circ} \mathrm{C}\right)$.

The chilled products were heat treated with sous vide device (Instanta Ltd., Southport, England). During the heat treatment we measured the core temperature in every 10 minutes. After the core temperature reached $75^{\circ} \mathrm{C}$, we maintained the temperature for additional 30 minutes. We cooled down the parisers in ice cold water. (Seydelmann, Belam, Proman, Budapesti Húsipari Vállalat, Országos Húsipari Kutatóintézet, 1987.)

\section{Microbiological analysis}

The sausages were evaluated microbiologically on the 1 and 19 days of the storage. The samples were analysed using standard procedures for Staphylococcus aureus (S. aureus) on Baird Parker agar (Biolab Ltd, Budapest, Hungary) at $37{ }^{\circ} \mathrm{C}, 48 \mathrm{~h}$ Clostridium perfringens $(C$. perfringens) on Tryptose Sulfite Cycloserine agar (Biolab Ltd, Budapest, Hungary) at $37^{\circ} \mathrm{C}, 48 \mathrm{~h}$, Enterococcus faecalis on Citrate acid tween carbonateagar (Biolab Ltd, Budapest, Hungary) $\left(35^{\circ} \mathrm{C}\right.$, 24h), coliforms and Escherichia coli (E. coli) on ChromoCult Coliform agar (Biolab Ltd, Budapest, Hungary) $\left(37^{\circ} \mathrm{C}, 48 \mathrm{~h}\right)$. The used herbs were also analysed for yeast and molds on Yeast Glucose Chloramphenicol (Biolab Ltd, Budapest, Hungary) $\operatorname{agar}\left(25^{\circ} \mathrm{C}, 120 \mathrm{~h}\right)$.

For S. aureus we used confirmation test Staph Latex kit (Pro-lab Diagnostic, Birkenhead, England), which is an agglutination test.

\section{Agar diffusion test}

We tested the commercial herbs if they have inhibition effects on E. coli and S. aureus. We made solutions of $E$. coli and $S$. aureus. We made solutions of the herbs too, 0.05, 0.1 and $1 \mathrm{~g} / 10 \mathrm{~mL}$ sterile diluting water. We used Tryptic soy agaragar and drilled holes into it, four holes to the three herbs and one empty as control. Then we filled the holes with $200 \mu \mathrm{L}$ of solutions.

\section{Nutrition content analysis}

The Directive 1-3/13-1 of the Codex Alimentarius Hungaricus clearly and strictly defines the products most important components in intervals, these are the protein, fat, moisture and sodium-chloride contents.

The protein content of the pariser was determined by sulphuric acid digestion and then titration. The fat content was determined by acido-butirometric method which is a sulphuric acidic digestion. The sodiumchloride content was determined by Mohr-method which is a precipitation titration. The moisture content was determined by drying in a drying oven, the samples were measured before and after the drying (Lencsepeti and Lörincz, 1973).

\section{RESULTS}

\section{Microbiology results}

\section{Staphylococcus aureus}

The Decree No. 4 of 1998 of the Ministry of Health clearly regulate several microorganisms presence in meat products. $S$. aureus in meat products should not reach the $10^{4}$ colony forming unit per grams. In the case of the first production we did not find typical colonies of $S$. aureus on the BP dishes. We tested samples from the same production, but they were vacuum sealed and kept in fridge on $4{ }^{\circ} \mathrm{C}$. The second tests showed the same results like the first, we could not find typical colonies of $S$. aureus, so we concluded our products are acceptable by the decree for S. aureus.

We repeated the production with the same recipe and under the same conditions. In the case of thyme flavoured pariser we found typical colonies, in the value of $8.57 \times 10^{3} \mathrm{cfu} / \mathrm{g}$. An in the case of the oregano flavoured pariser, in the value of $4.76 \times 10^{1} \mathrm{cfu} / \mathrm{g}$. Both are under the $10^{4} \mathrm{cfu} / \mathrm{g}$ limit value, so both were acceptable, but we thought the value in the case of thyme flavoured pariser is high, even if it did not reach the limit of the decree. We did not test more the second production for S. aureus. 
The confirmation tests were positive for $\mathrm{S}$. aureus in every case.

\section{Clostridium perfringens}

We tested both of the productions for Clostridium perfringens, but none of the samples contained it, so we did not test the samples again for $C$. perfringens.

\section{Enterococcus faecalis}

We tested both of the productions for Enterococcus faecalis, but none of the samples contained it, so we did not test the samples again for E. faecalis.

\section{Yeast and mould}

We tested the used herbs and the base pariser spice mix for yeast and mould. In the cases of thyme and the base spice mix the dishes were clean, nothing started to grow. But on the dishes of oregano and sage we found $2.76 \times 10^{2}$ and $1.76 \times 10^{2} \mathrm{cfu} / \mathrm{g}$.

\section{Eschericia coli and coliforms}

We tested the commercial spices and our products for E. coli and coliforms. In case of herbs it is mandatory, but the law does not regulate the processed meat product's $E$. coli number.

The herbs and base spice did not contain any E. coli or coliforms, only the commercial sage sample what we used for one of our product, contained $2.99 \times 10^{3}$ colony forming unit per gram coliforms. The law only regulates the number of E. coli colonies, which's maximum value is $10^{4} \mathrm{cfu} / \mathrm{g}$.

In the case of the first production we didn't find any typical E. coli or coliforms colonies on the dishes, but we tested them again 17 days later, when all the pariser's dishes were clean again.

Our next production sadly contaminated and we found in the case of the zero day's analysis coliforms on the dishes. On the thyme flavoured pariser's dish $6.27 \times 10^{2} \mathrm{cfu} / \mathrm{g}$, the dish of oregano flavoured pariser $4.57 \times 10^{2} \mathrm{cfu} / \mathrm{g}$, and in case of the dish of sage flavoured pariser $1.93 \times 10^{2} \mathrm{cfu} / \mathrm{g}$.

\section{Agar diffusion test}

Only the thyme samples had some kind of inhibition against $S$. aureus and $E$. coli. In the cases of sage and oregano we could not find any inhibition. The radiuses of the inhibition zones of thyme were $12-15 \mathrm{~mm}$. The biggest inhibition $(15 \mathrm{~mm})$ was for $S$. aureus, in the case of $1 \mathrm{~g} / 10 \mathrm{~mL}$ solution.

In the case of sage not only the inoculated bacterias appeared on the dishes, but the flora of the sage too.

\section{Nutritional tests \\ Fat content}

Both of our pariser production reached the same fat content results, $18.34 \mathrm{~g} / 100 \mathrm{~g}$ of product. The Directive 1-3/13-1 of the Hungarian Codex Alimentarius determines the fat content of the pariser, which is maximum $20 \%$ of the product. According to the fat content our product can be named pariser. (Codex Alimentarius Hungaricus, 2016.)

\section{Protein content}

In both production's cases the pariser's protein content were $15.11 \mathrm{~g} / 100 \mathrm{~g}$ of product. The Directive 13/13-1 of the Hungarian Codex Alimentarius determines the protein content too which is minimum $11 \%$. Our products had $15,11 \%$, so according to the regulation of protein content our product can be named pariser. (Codex Alimentarius Hungaricus, 2016.)

\section{Salt content}

In the case of the first production the salt content was $1.2 \%$, which was low even according to the people who tasted the product. We supplemented the salt content for $2.2 \%$, which is the maximum allowed value of salt in pariser.

\section{Water content}

According to the Directive 1-3/13-1 of the Hungarian Codex Alimentarius the water content of pariser can be maximum $70 \%$. We measured little differences (Table 1). The thyme flavoured pariser contained $34.3 \pm 1.1 \%$ water. The sage flavoured pariser contained $34.4 \pm 0.4 \%$ water. The oregano flavoured pariser had exactly $35.4 \%$ water content. The control pariser had $35.6 \pm 0.4 \%$ of water. (Codex Alimentarius Hungaricus, 2016.)

We were curious about how much is the difference between the commercial products and our pariser in terms of the water content too. We bought three commercial product (Spar Ltd., Amsterdam, The Netherlands; Pick Szeged Ltd., Szeged, Hungary; Wiesbauer Gmbh, Vienna, Austria) and tested their water content with the same method.

The commercial products had higher water content than our product, nearly twice.

\section{Comparison of the water content of the parisers from commercial source and our products}

\begin{tabular}{lc}
\hline \multicolumn{1}{c}{ name of the sample } & water content $(\%)$ \\
\hline thyme pariser & $34.3 \pm 1.1$ \\
sage pariser & $34.4 \pm 0.4$ \\
oregano pariser & 35.4 \\
control pariser & $35.6 \pm 0.4$ \\
pariser from Spar & $66.5 \pm 0.1$ \\
pariser from Pick & $63.5 \pm 0.1$ \\
pariser from Wiesbauer & $68.1 \pm 0.3$ \\
\hline
\end{tabular}

According to the regulation of water content our product is pariser (Table 2). Of course with the higher meat and lower water content it does not have place on the market because the price would be higher. 
Table 2

The parameters of the our pariser and the recommended parameters by Directive 1-3/13-1 of the Codex Alimentarius (Codex Alimentarius Hungaricus, 2016

\begin{tabular}{lcc}
\hline & recommendation & our products \\
\hline fat content $(\%)$ & $23>$ & 18.3 \\
protein content $(\%)$ & $11<$ & 15.1 \\
salt content $(\%)$ & $2.2>$ & $1.2 ; 2.2$ \\
water content $(\%)$ & $70>$ & 35 \\
\hline
\end{tabular}

\section{DISCUSSION}

Our product according to the Directive 1-3/131 of the Hungarian Codex Alimentarius is pariser and has better parameters than the commercial products, but with this recipe unprofitable because of the higher meat and lower water content.

The inhibitory effect of the used herbs were not as strong as the plant originated extracts like essential oils, but they have positive effects on the organoleptic properties of the product, but not on the microbial state. Using essential oils in food can cause several issues which can be harmful for the human health.

\section{ACKNOWLEDGEMENTS}

The publication was supported by the project No. EFOP-3.6.2-16-2017-00012, „Developing a functional, healthy and safe product chain model from field to table in a thematic research network". The project was founded by the European Union and co-financed by the European Social Fund.

\section{REFERENCES}

Agaoglu, S.-Dostbil, N.-Alemdar, S. (2007): Antimicrobial activity of some spices used in the meat industry, Bulletin of the Veterinary Institute in Pulawy. 51: 53-57.

Bakkali, F.-Averbeck, S.-Averbeck, D.-Idaomar, M. (2008): Biological effects of essential oils. A review. Food Chemical Toxicology 46, 446-475. (https://www.sciencedirect.com/science/article/pii/S027869150 7004541)

Burt, S. (2004): Essential oils: Their antibacterial properties and potential applications in foods - A review. International Journal of Food Microbiology, 94(3), 223-253. (https://www.sciencedirect.com/science/article/pii/S016816050 4001680?via\%3Dihub)

Burt, S. A.-Der Zee, R. V.-Koets, A. P.-De Graaff, A. M.-Van Knapen, F.-Gaastra, W. (2007): Carvacrol induces heat shock protein 60 and inhibits synthesis of flagellin in Escherichia coli O157:H7. Applied and Environmental Microbiology, 73, 4484-4490. (https://www.ncbi.nlm.nih.gov/pmc/articles/PMC1932834/)

Chen, N.-Chang, C. C.-Nn, C. C.-Wang, C. Y.-Shyu, Y. T.-Chang, T. L. (2008): Antioxidant and antimicrobial activity of Zingiberaceae plants in Taiwan. Plant Foods for Human Nutrition, 63(1), 15-20. (https://www.ncbi.nlm.nih.gov/pubmed/18157743)

Codex Alimentarius Hungaricus (2016): I. volume, Regulation number 1-3/13-1 about meat products and certain prepared meat products (https://elelmiszerlanc.kormany.hu/download/0/17/72000/ME\% 201-3_13-1\%20-\%2020190923-notifik\%C3\%A1lt.pdf)
Holley, R. A.-Patel, D. (2005): Improvement in shelf-life and safety of perishable foods by plant essential oils and smoke antimicrobials. Food Microbiology, 22(4), 273-292. (https://www.sciencedirect.com/science/article/pii/S074000200 4001042)

Lencsepeti, J.-Lőrincz, F. (1973): Húsipari kézikönyv, Mezőgazdasági Kiadó.

Mosqueda-Melgar, J.-Raybaudi-Massilia, R. M.-Martin-Belloso, O. (2008): Inactivation of Salmonella enterica Ser enteritidis in tomato juice by combining of high-intensity p $\mu$ Lsed electric fields with natural antimicrobials. Journal of Food Science, 73(2), 47-53. (https://onlinelibrary.wiley.com/doi/abs/10.1111/j.17503841.2007.00646.x)

Seydelmann, Belam, Proman, Budapesti Húsipari Vállalat, Országos Húsipari Kutatóintézet (1987): Vörösáru, kenősáru és nyerskolbász technológia, Húsok befecskendezése és masszírozása, Beef-A-Matic: a csontozás korszerủ módszere, Szimpózium.

Sikkema, J.-De Bont, J. A.-Poolman, B. (1995): Mechanisms of membrane toxicity of hydrocarbons. Microbiology Review 59, 201-215. (https://www.ncbi.nlm.nih.gov/pmc/articles/ PMC239360/) 